\title{
Relation between climatic cariables and tomato powdery mildew caused by Leveillula taurica
}

\section{S. A. Zayan}

Plant Pathology Research Institute, A.R.C, Giza, Egypt.

\begin{abstract}
Tomato powdery mildew caused by Leveillula taurica is a severe disease that infects all aerial parts of tomato, excluding the fruits. The aim of this paper was to observe factors that influence the development of Leveillula taurica on tomato. In vitro and under controlled conditions, we observed the rates of conidial germination at temperature degrees of $10,15,20,25,30$ and $35^{\circ} \mathrm{C}$. Also, the same experiment was applied but with different relative humidity $(\mathrm{RH})$ levels of 50,65, 75, 85 and $100 \%$. Optimal conditions for appressoria formation were $30^{\circ} \mathrm{C}$ and $100 \% \mathrm{RH}$. For four different growing seasons, data were collected from tomato fields located in Behera and Giza Governorates involving various climatic parameters collected by Agro-Weather Stations. The collected data was then used to estimate correlations regarding the effects of temperature and $\mathrm{RH}$ on the disease severity. Severity of powdery mildew was positively correlated with the range of 15 to $30^{\circ} \mathrm{C}$ and $\mathrm{RH}$ levels of 60 to $100 \%$. Temperatures in the low and the high ranges $\left(5\right.$ to $10^{\circ} \mathrm{C}$ and 35 to $40^{\circ} \mathrm{C}$ ) and relative humidity less than $60 \%$. These conducted results suggest that the combination of high temperatures and high $\mathrm{RH}$ provides the highest severity of powdery mildew (caused by Leveillula taurica) in tomatoes fields.
\end{abstract}

Keywords: Leveillula taurica, powdery mildew and tomato.

Tomato is one of the most significant crops around the world. It is produced and consumed for both the fresh fruit market and the processed food industries. Egypt is ranked as one of the highest five countries in tomato production all over the world; where the total production reached nearly 8.5 million tons (FAOSTAT, 2013). Consequently, it is one of the most important crops to look for methods in order to increase its quantity and quality.

Tomato powdery mildew caused by Leveillula taurica may cause losses of up to $40 \%$ of tomato crop yields (Jones and Thomson, 1987). The losses depend on various parameters like environmental conditions, time of appearance of disease infection, and effectiveness of fungicide control.

Powdery mildew is very easy to identify, as its symptoms are fairly unique. On one side, the infected tomato leaves grow irregular, bright yellow blotches; severely affected leaves die but rarely drop. Spots of dead tissue, sometimes bordered by a yellow halo, eventually appear in the blotches. On the other side, the infected plants show white powdery spots on the leaves which may also appear on stems. Although powdery mildew can appear on any above-ground part of the plant, it mostly affects 
the lower leaves. As the disease grows leaves die which results in sunburn damage on fruit, reduced soluble solids, and weakened plants (Reis et al., 2005).

High humidity and moderate to high temperature are the perfect environments within condition for powdery mildew incidence. In an agriculture field, different techniques, i.e. chemical methods (Keinath and DuBose, 2004 and Anand et al., 2010), biological control (Keinath and DuBose, 2004 and Anand et al., 2010), genetic resistance (Chunwongse et al., 1994 and Bai et al., 2003) and other scan be used in controlling disease pathogens.

The reduction of fungicide application is a target for all parties of interest from growers to consumers. Using disease management programs helps in reducing the number of fungicide applications which reduces production costs, potential residues on the product, and risk of development of fungicide resistance in the pathogens. There are ways to reduce the amount of required fungicide applications without intimidating disease control. One of these ways is using disease warning systems that predict possible outbreaks or increases in disease severity based on the weather parameters. According to the Intergovernmental Panel on Climate Change (IPCC), climate change will cause global mean temperatures to rise by 2 to $3 \mathrm{~K}$ in the next 50 years (IPCC, 2011). Also, there will be a change in the intensity of precipitation events and seasonal precipitation distributions. For these reasons, problems such as early summer drought may get worse and the possibility of severe weather events could increase. Consequently, all this will have a great effect on plant disease incidence, pest occurrence and plant protection. As, using fungicide application only when microclimate conditions are suitable for powdery mildew incidence is a main strategy in order to reduce the amount of chemicals required to control the disease (Guzman-Plazola, 1997).

Therefore, the aim of this study was studying the weather parameters and their correlating with the disease incidence and disease severity which plays a great role in producing an accurate disease warning systems; which by default has a great impact on crop production quality and quantity.

\section{$M$ aterials and Methods}

Effect of some environmental factors on the causal fungus:

In vitro, two experiments were conducted in order to specify the effect of different degrees of temperature, and relative humidity on the conidial germination of L. taurica. Collected data were analyzed by statistical analysis program ASTAT.

\section{Experiment 1: Effect of temperature on conidial germination:}

Naturally infected tomato leaves with powdery mildew were shaken on glass slides, followed by putting each two slides on a glass rode in a Petri dish bottled with moist filter paper to maintain 100\% R.H. The prepared Petri dishes were sealed with plaster, and then incubated at different degrees of temperature, i.e.10, 15, 20, 25,30 and $40^{\circ} \mathrm{C}$ for 12 and 24 hours. At each degree of temperature, three replicates were used. The average percentage of germinated conidia was recorded, and was calculated by: (No. of germinated conidia)/(Total no. of conidia) 
Experiment 2: Effect of RH on conidial germination:

In this experiment, five different levels of relative humidity (RH), i.e. 50, 65, 75, 85 and $100 \%$ were set using sulphuric acid and distilled water as explained by Mclean and Cook (1951). Ten $\mathrm{ml}$ from the prepared solution were distributed in each Petri dish to provide the desired RH level. Naturally infected tomato leaves showing heavy infection with L. taurica were shaken on the cavity of glass slides. Afterward, each two slides were put onto glass rode in each dish containing the desired RH level. The dishes were sealed with plaster, and then incubated at $25 \pm 1{ }^{\circ} \mathrm{C}$ for 12 and 24 hours. Three replicates of Petri dishes were used for each treatment. The average percentage of germinated conidia was recorded, and was calculated using the formula by $\%$ germinated canadia: No. of germinated conidia, Total No. of conidia.

Experiment 3: Effect of temperature and relative humidity on disease severity in the field:

In vivo, the cultivar (Super Marmande) was planted in two Governorates Giza and Behera.

The experiments were conducted as randomized complete blocks design where the area of each plot was $7.5 \mathrm{~m} 2$. Transplants were planted in a clay soil, where each plot was one ridge of 6 meters in length and 1.25 meters in width and the distance between plants was $50 \mathrm{~cm}$ apart. The same way was applied for the 4 seasons from August to November for both 2013 and 2014, and from March to June 2014 and 2015 in both locations. An automated agro-weather station (Adcon telemetry) with temperature and relative humidity sensors programmed to collect data every hour and giving a daily reading was installed at each field at the level of the plant's aerial parts. At the beginning of each season, the weather station was put in a protecting container and located in the canopy of tomatoes in the field. As the plants grew, the station transferred to be in the middle of the field. Daily microclimate data were collected by the station. Characterization of L. taurica was confirmed by inspection of damaged leaflets with a microscope. The disease progress was evaluated by measuring disease severity which was measured every week using randomized samples from each plot according to Horsfall and Barrat (1945). In this experiment, the correlation was applied to the collected data starting from the first day where the plant is considered susceptible to powdery mildew infection till harvesting date. Data were analyzed using Spearman rank correlation which is a non-parametric assessment that is used to compute the degree of association between two variables. This correlation was chosen as it does not assume any assumptions about the distribution of the data and the data don't have to be linear which applies for our collected data.

\section{Res u l t s a n d D is c u s s i o n}

In vitro effect of different temperatures on conidial germination:

Data tabulated in Table (1) and Figs. (1) show that germination of conidia occurred at temperature ranged from $10^{\circ} \mathrm{c}$ up to $40^{\circ} \mathrm{c}$ after $12 \mathrm{hrs}$ and $24 \mathrm{hrs}$. The best temperature for spore germination was estimated to be around $30^{\circ} \mathrm{c}$ after $24 \mathrm{hr}$, being $46.4 \%$, while the least conidial germination was $11.5 \%$, after $12 \mathrm{hr}$. incubation at $10^{\circ} \mathrm{c}$. There were positive correlation between temperature between $10^{\circ} \mathrm{c}-35^{\circ} \mathrm{c}$ and 
percentage of spore germination after $12 \mathrm{hrs}$ and $24 \mathrm{hrs}$, while they were negatively correlated between $35^{\circ} \mathrm{c}$ and $40^{\circ} \mathrm{c}$.

Table 1. Effect of different degree of temperature on the conidial germination of Leveillula taurica, after 12 and $24 \mathrm{hr}$. of incubation

\begin{tabular}{|c|c|c|c|}
\hline \multirow{2}{*}{$\begin{array}{c}\text { Temperature } \\
\left({ }^{\circ} \mathrm{C}\right)\end{array}$} & \multicolumn{2}{|c|}{ Germination (\%) after } & $\overline{\mathrm{X}}$ \\
\cline { 2 - 3 } & $12 \mathrm{hr}$ & $24 \mathrm{hr}$ & 19.4 \\
10 & 11.5 & 27.2 & 22.6 \\
20 & 13.6 & 31.5 & 25.0 \\
25 & 15.1 & 34.9 & 30.0 \\
30 & 17.8 & 42.2 & 32.8 \\
35 & 19.2 & 46.4 & 26.9 \\
40 & 16.3 & 37.5 & 23.5 \\
\hline Mean & 14.6 & 32.4 & - \\
\hline L.S.D (0.05) for Temp.: & 15.4 & 36.0 & \\
\hline
\end{tabular}

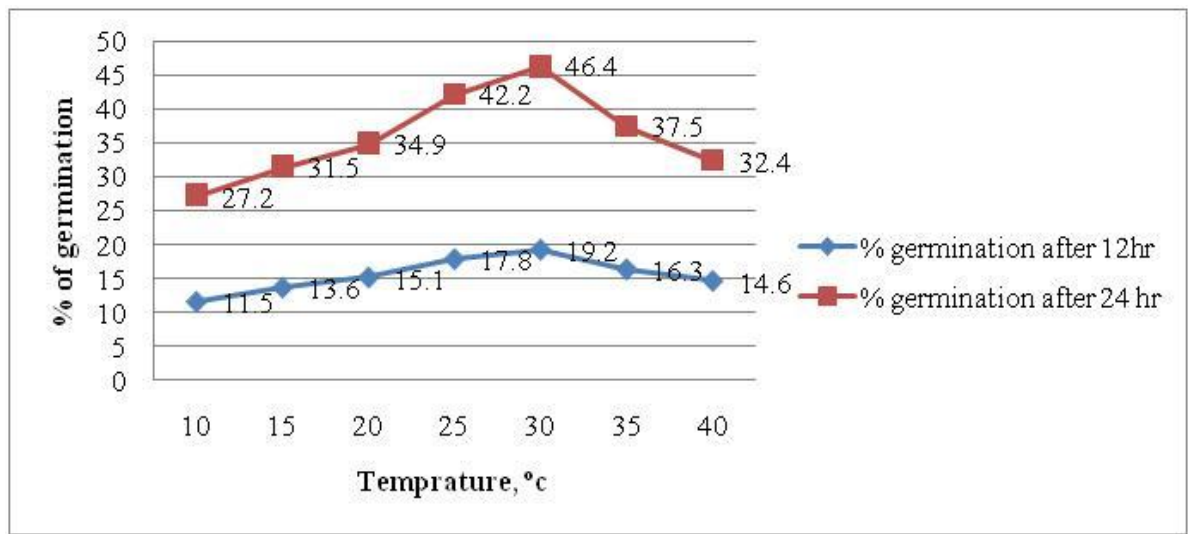

Fig. 1. Effect of different degrees of temperature on the conidial germination of Leveillula taurica after 12 and 24 hr of incubation.

In vitro effect of relative humidity $(R H)$ on conidial germination:

Conidia of $L$. taurica were transferred into Petri dishes containing different solutions to give different levels of RH to study their effect on spore germination. Data presented in Table (2) and illustrated in Fig. (2) evidently show that high humidity is essential for spore germination. The best results, being 43.6, 48.4, and $52.3 \%$ were obtained due using 75, 85 and 100RH levels for $24 \mathrm{hrs}$. Obviously, RH at $100 \%$ is the optimal. There were positive correlation between percentage of relative humidity and percentage of spore germination.

3. In vivo effect of temperature and Relative Humidity on Disease Severity:

The results of our analysis for the effect of selected weather parameters on powdery mildew severity are presented in Figs. (3)-(10). Regarding relationships between temperatures and powdery mildew severity levels, there were positive 
correlations in the temperature range from 15 to $30^{\circ} \mathrm{C}$ and relative humidity more than $60 \%$. Conversely, the negative correlations were observed from 35 to $40^{\circ} \mathrm{C}$.

Table 2. Effect of different levels of relative humidity on the conidial germination of Leveillula taurica after 12 and $24 \mathrm{hr}$. of incubation

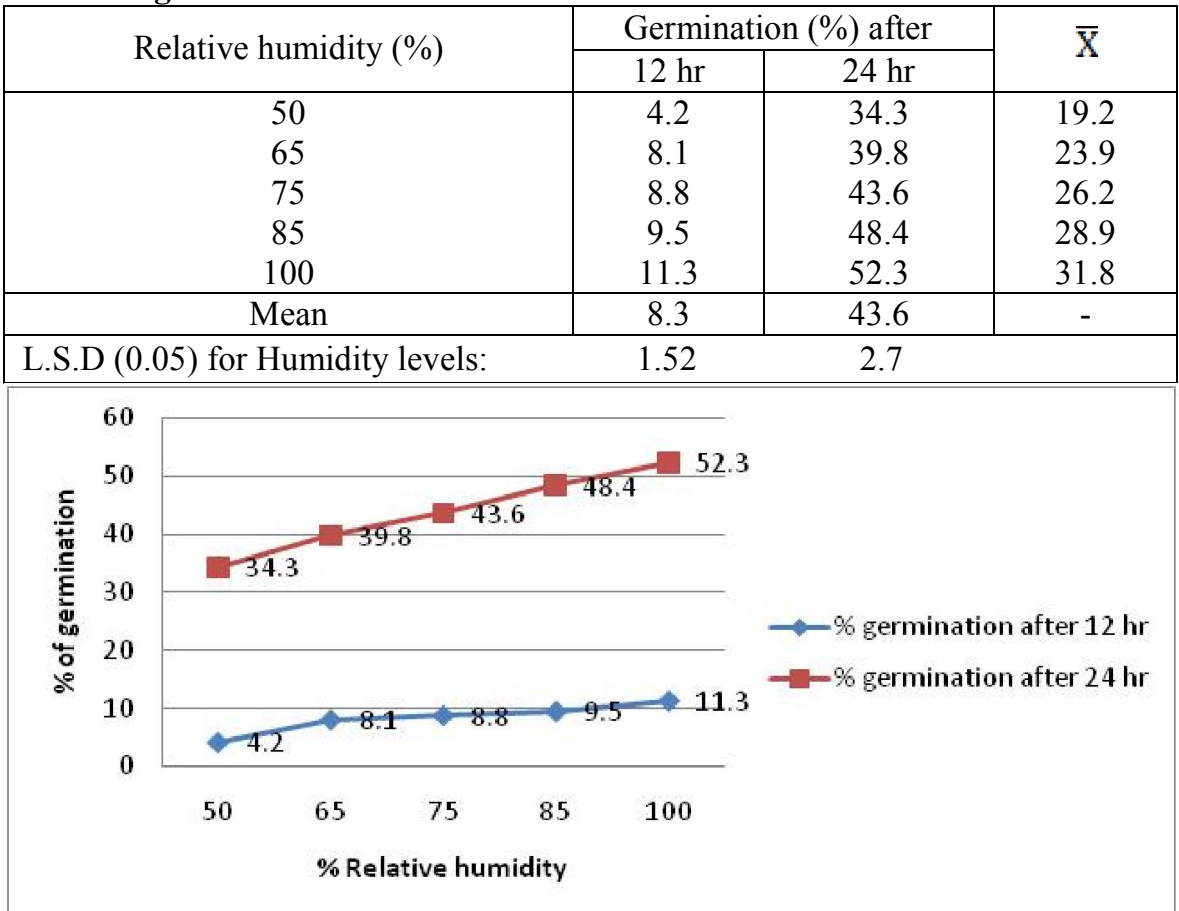

Fig. 2. Effect of different levels of relative humidity on the conidial germination of Leveillula taurica after 12 and $24 \mathrm{hr}$. of incubation.

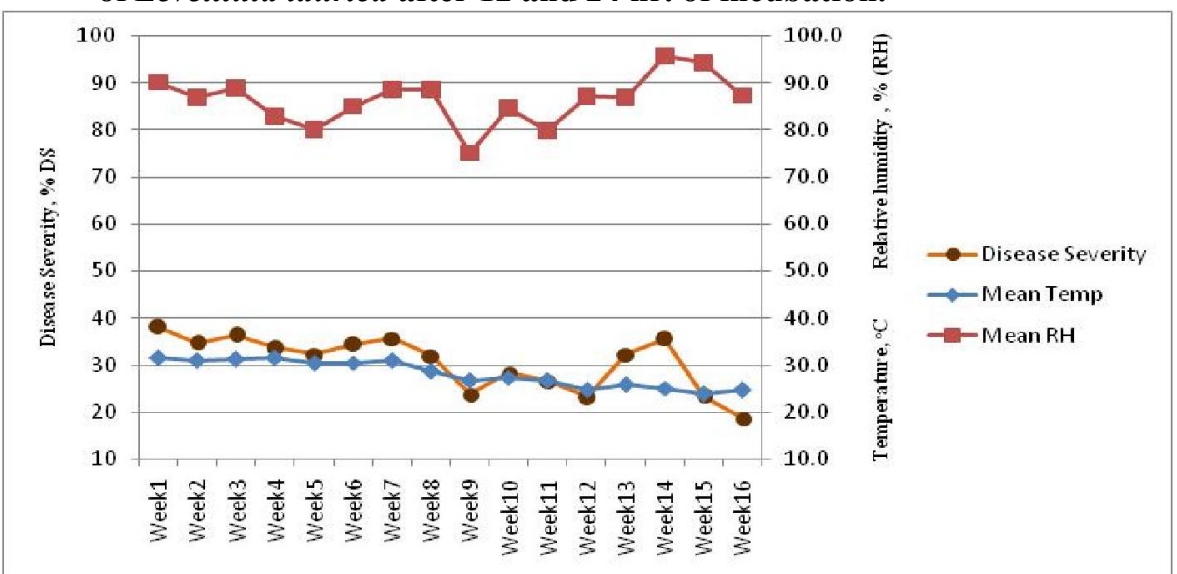

Fig. 3. Effect of temperature and relative humidity levels on disease severity on tomato grown from August to November 2013, Behera Governorate. 


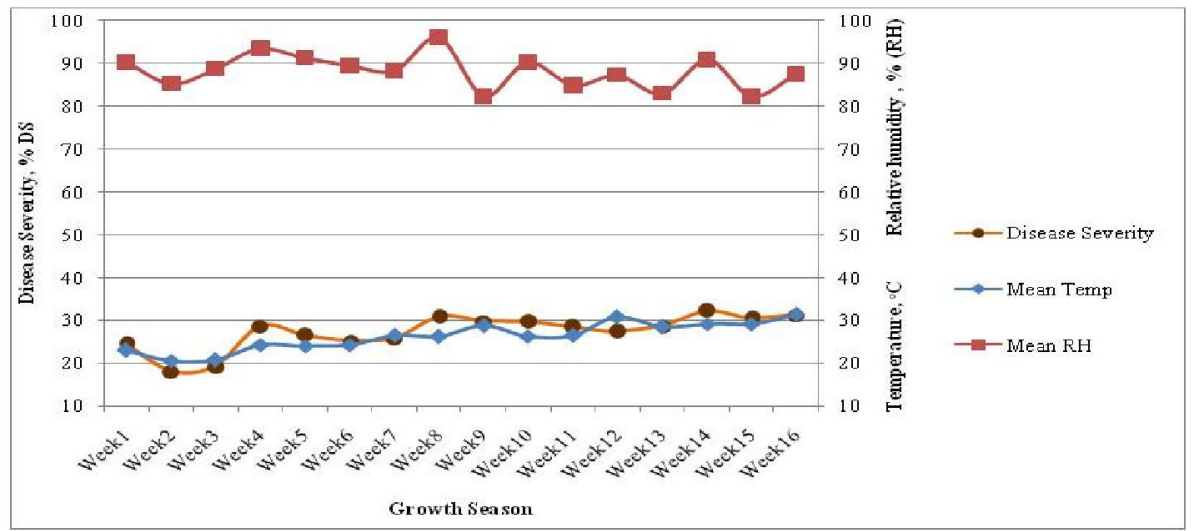

Fig. 4. Effect of temperature and Relative humidity levels on disease severity on tomato grown from March to June 2014, Behera Governorate.

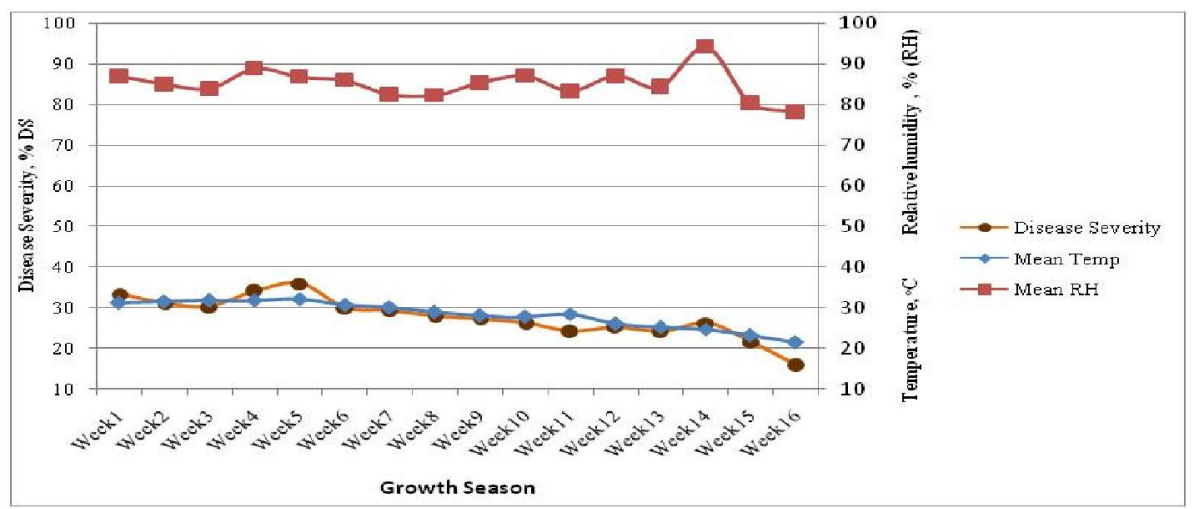

Fig. 5. Effect of temperature and Relative humidity levels on disease severity on tomato grown from August to November 2014, Behera Governorate.

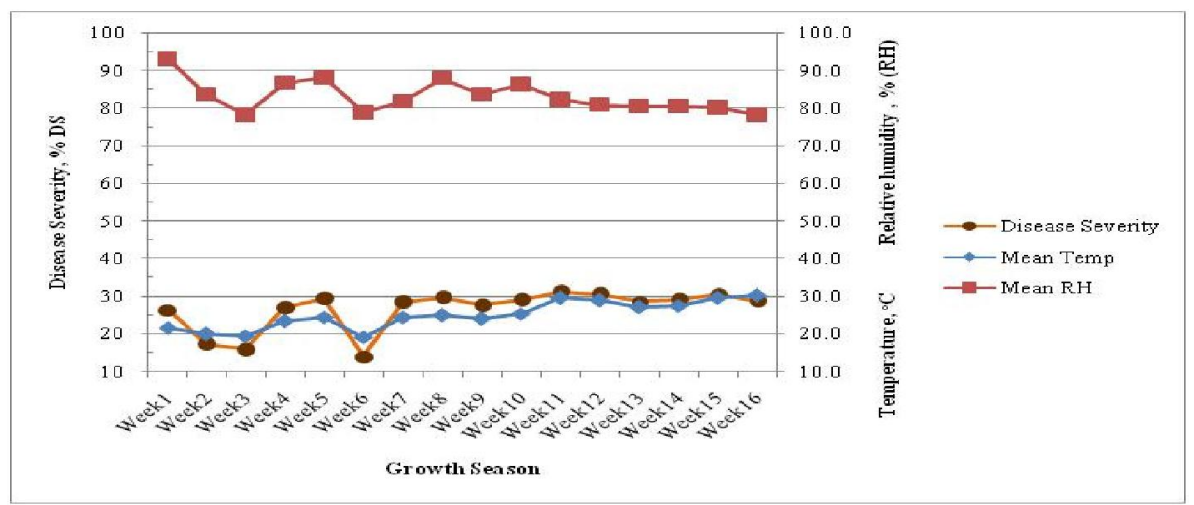

Fig. 6. Effect of temperature and Relative humidity levels on disease severity on tomato grown from March to June 2015, Behera Governorate.

Egypt. J. Phytopathol., Vol. 44, No. 1 (2016) 


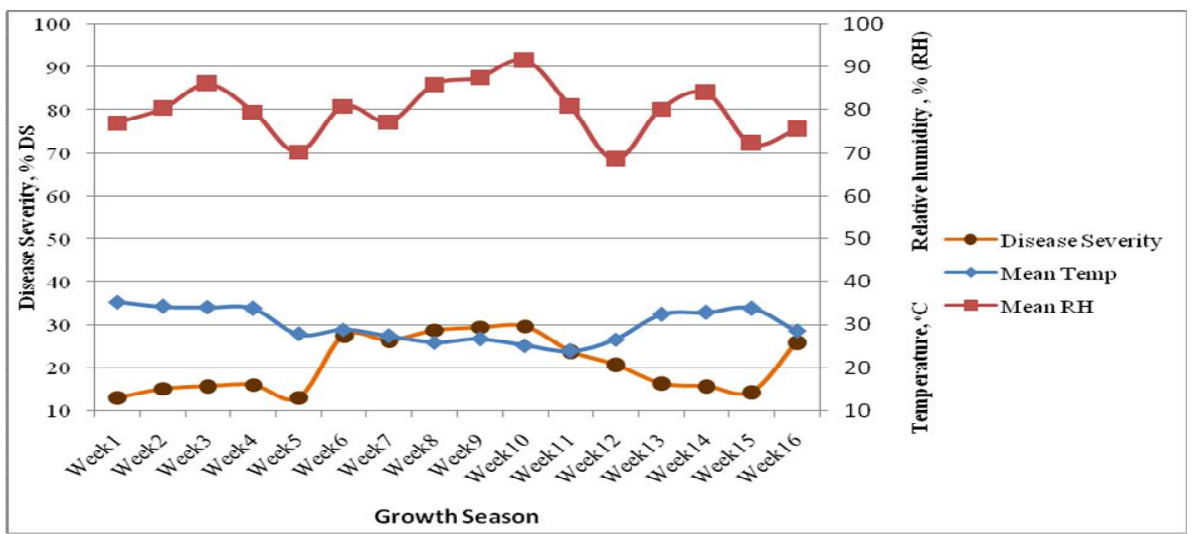

Fig. 7. Effect of temperature and Relative humidity levels on disease severity on tomato grown from August to November 2013, Giza Governorate.

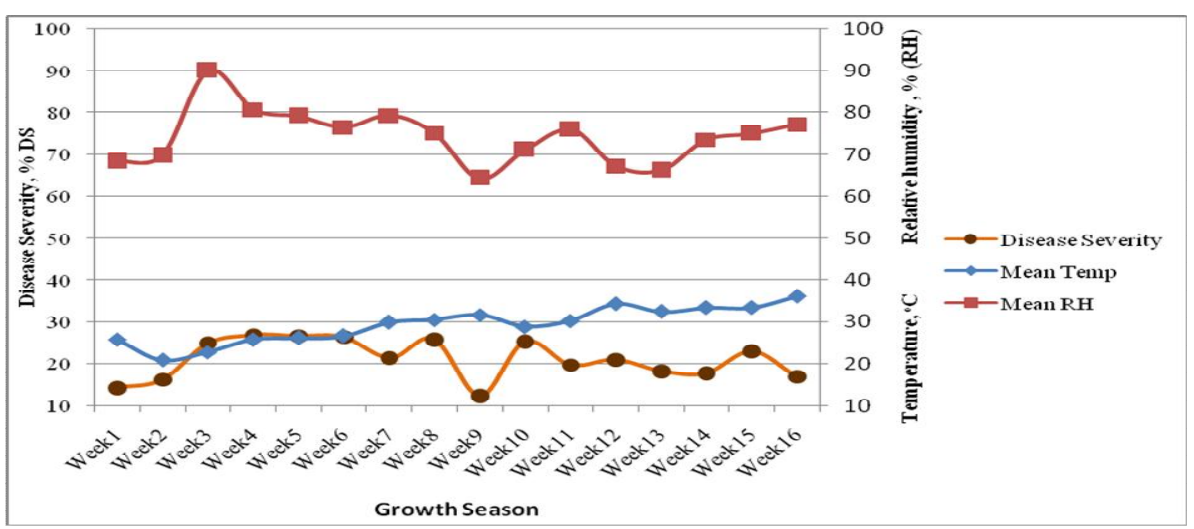

Fig. 8. Effect of temperature and Relative humidity levels on disease severity on tomato grown from March to June 2014, Giza Governorate.

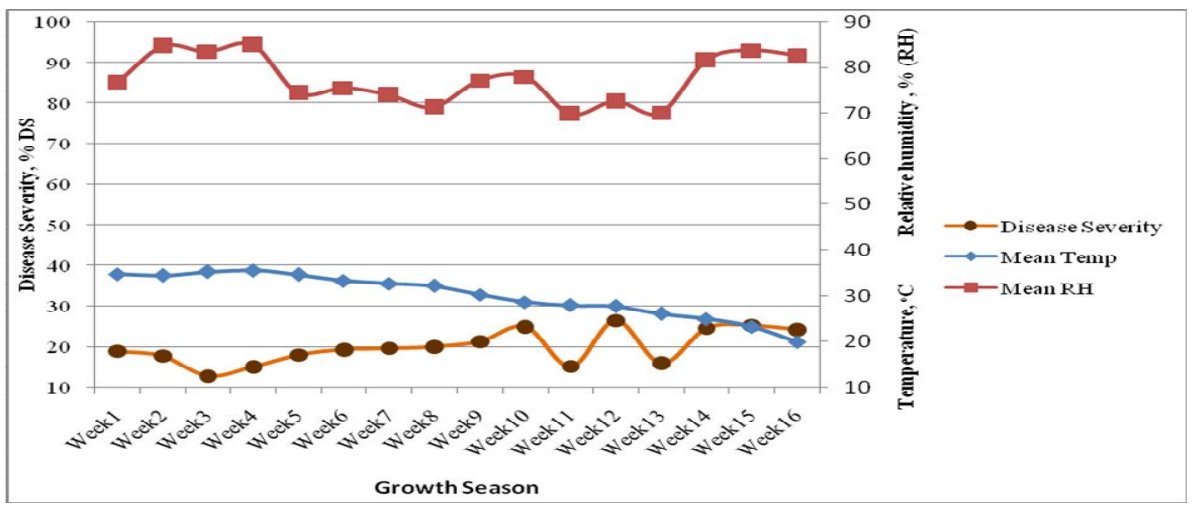

Fig. 9. Effect of temperature and Relative humidity levels on disease severity on tomato grown from August to November 2014, Giza Governorate. 


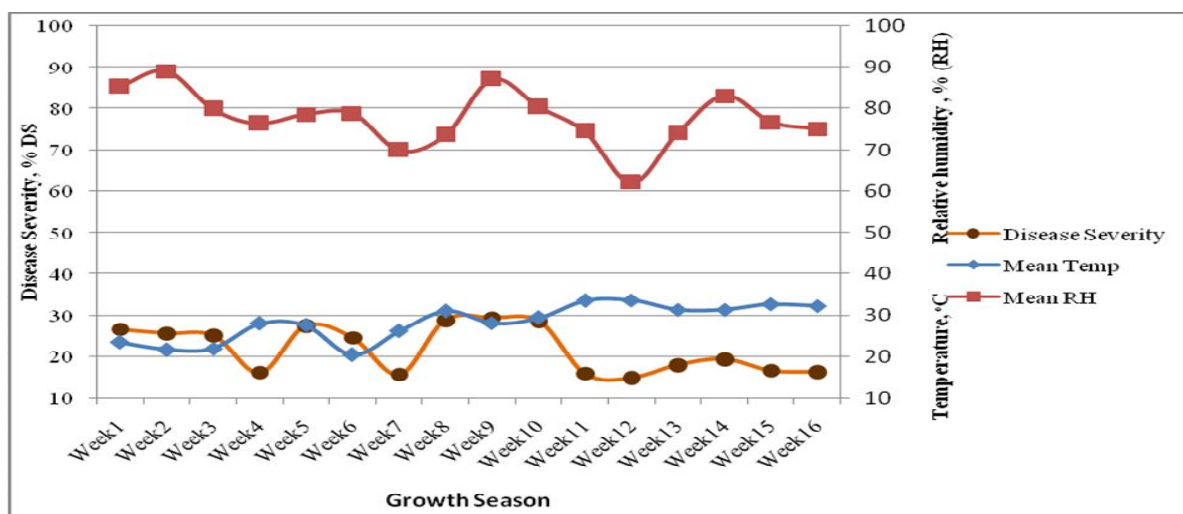

Fig. 10. Effect of temperature and Relative humidity levels on disease severity on tomato grown from March to June 2015, Giza Governorate.

According to the obtained data, the rates of spore germination are proportional to the RH level where as RH level gets higher the rate of germination increases. The greatest spore germination would occur at the highest possible air humidity $(100 \%$ $\mathrm{RH})$. This outcome is compatible with other studies on powdery mildews where most spore germination was reached at RHs near to $100 \%$ (Yarwood, 1957; Butt, 1978 and Husain and Akram, 1995). On the other hand, spore germination progress was generally higher at $30^{\circ} \mathrm{c}$ than at $25^{\circ} \mathrm{c}$. While the germination started decreasing at temperature range from $35^{\circ} \mathrm{c}$ till $40^{\circ} \mathrm{c}$. On contrary, the generated results didn't agree with other studies which indicated the absence of spore germination at temperature $30^{\circ} \mathrm{C}$ or higher (Munshi and Singh, 1994; Guzman et al., 2003).

Two data of the effect extreme of weather data in field during the selected periods through 2013 and 2014 growing seasons in two governorates (Behera and Giza) on disease severity of tomato powdery mildew indicated that there was a positive relation between disease severity and temperature in range from $20{ }^{\circ} \mathrm{c}$ to $30^{\circ} \mathrm{c}$ with high relative humidity (more than $60 \%$ ). On the other hand, temperature from $35^{\circ} \mathrm{c}$ and above showed negative track even in case of high humidity. It should be noted that the collection of data analysis in work station is hourly and this amount of data cannot be represented on graph but can be used by weekly averages. In some cases, it was noticed that in days with relative humidity less than $60 \%$ during the week, disease severity percentage during the whole week was affected. This observation was noticed in last week of November 2014 at Behera governorate. While in Giza, this incident was noticed more than once, during the $5^{\text {th }}, 11^{\text {th }}$ and $13^{\text {th }}$ weeks of summer season 2013. Also, the same episode was repeated during the $1^{\text {st }}$, $2^{\text {nd }}, 7^{\text {th }}$ and $11^{\text {th }}$ week of the spring season 2014; then again in the 11 th and 13th weeks of summer 2014. Finally, it occurred in the $4^{\text {th }}$ and $7^{\text {th }}$ weeks of spring 2015.

\section{Refer e n c es}

Anand, T.; Chandrasekaran, A.; Kuttalam, S.; Senthilraja, G. and Samiyappan, R. 2010. Integrated control of fruit rot and powdery mildew of chilli using the biocontrol agent Pseudomonas fluorescens and a chemical fungicide. Biol. Control, 52: 1-7. 
Anonymous 2013. Food and Agriculture Organization of the United Nations, FAOSTAT database (FAOSTAT, 2013). http://faostat3.fao.org/browse/Q/QC/E.

Anonymous, 2011. IPCC Special Report on Renewable Energy Sources and Climate Change Mitigation. Technical Report, Working Group III of the Intergovernmental Panel on Climate Change, New York, NY, USA.

Bai, Y.; Huang, C.C.; van der Hulst, R.; Meijer-Dekens, F.; Bonnema, G.; and Lindhout, P. 2003. QTLs for tomato powdery mildew resistance (Oidium lycopersici) in Lycopersicon parviflorum G1. 1601 co-localize with two qualitative powdery mildew resistance genes. Molecular Plant-Microbe Inter., 16(2): 169-176.

Butt, D.J., 1978. Epidemiology of powdery mildews, pp. 51-81. In: Spencer, D.M. (Ed.), The Powdery Mildews. Academic Press, New York, 565pp.

Chunwongse, J.; Bunn, T.B.; Crossman, C.; Jiang, J. and Tanksley, S.D. 1994. Chromosomal localization and molecular-marker tagging of the powdery mildew resistance gene (Lv) in tomato. Theoretical Applied Gen., 89(1): 76-79.

Guzman-Plazola, R.A. 1997. Development of a spray forecast model for tomato powdery mildew (Leveillula taurica (Lev) Arn). Ph.D. Thesis. University of California, Davis.

Guzman-Plazola, R.A.; Davis, R.M. and Marois, J.J. 2003. Effects of relative humidity and high temperature on spore germination and development of tomato powdery mildew (Leveillula taurica). Crop Prot., 22(10): 1157-1168.

Horsfall, J.G. and Barratt, R.W. 1945. An improved grading system for measuring plant diseases. Phytopathology, 35: 655.

Husain, S.I. and Akram, M. 1995. Effect of temperature and relative humidity on conidial germination and germ tube elongation of Sphaerotheca fuliginea (Schlecht. ex Fr.) Poll. on sun flower. J. Plant Dis. Prot., 102: 509-513.

Jones, W.B. and Thomson, S.V. 1987. Source of inoculum, yield, and quality of tomato as affected by Leveillula taurica. Plant Dis., 71: 266-268.

Keinath, A.P. and DuBose, V.B. 2004. Evaluation of fungicides for prevention and management of powdery mildew on watermelon. Crop Prot., 23: 35-42.

McLean, R.C. and Ivimey-Cook, W.R. 1951. Textbook of theoretical botany. London: Longmans, Green.

Munshi, G.D. and Singh, T. 1994. Effect of temperature and relative humidity on the development of Uncinula necator on grapes. Indian J. Mycol. Plant Pathol., (India).

Reis, A.; Boiteux, L.S.; Paz-Lima, M.L.; Silva, P.P. and Lopes, C.A. 2005. New hosts of Oidiopsis haplophylli in the Solanaceae family in Brazil. Fitopatol. Bras., 30: 195-198.

Yarwood, C.E. 1957. Powdery mildews. Bot. Rev., 23: 235-301.

(Received 24/02/2016;

in revised form 31/03/2016)

Egypt. J. Phytopathol., Vol. 44, No. 1 (2016) 


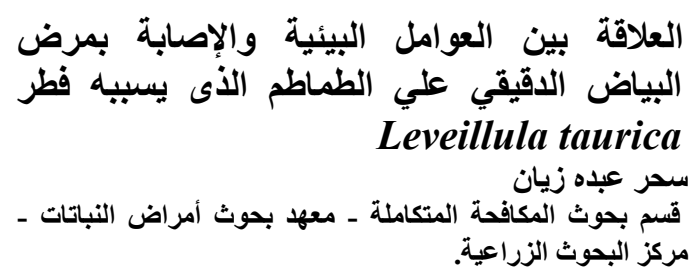

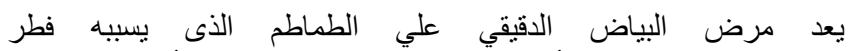
Leveillula taurica

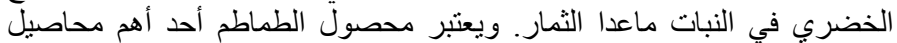

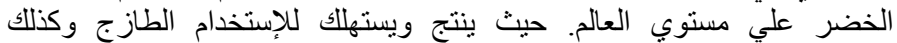

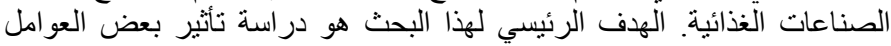

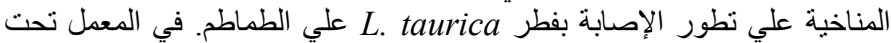

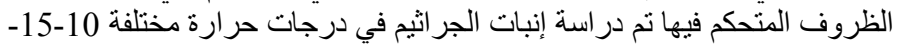

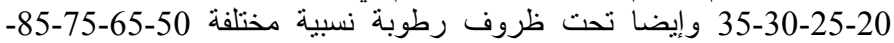

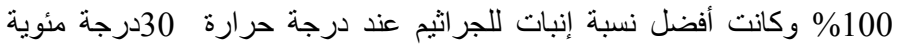
ورطوبة نسبية 100\%. وفي الحقل تم جمع بيانات العوامل المبن المناخية باستخدام

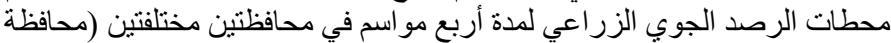

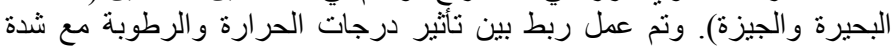

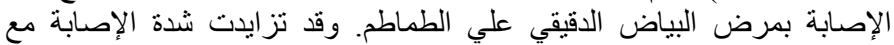

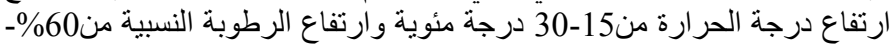

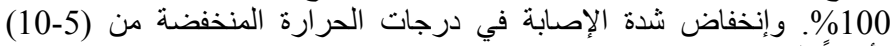

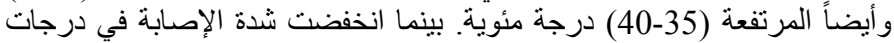

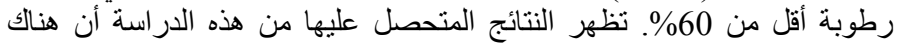

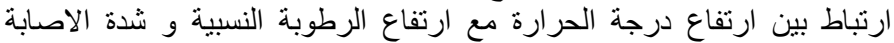

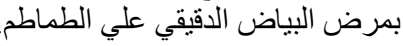

